\title{
Syngas Production via Methane Dry Reforming over La-Ni-Co and La-Ni-Cu Catalysts with Spinel and Perovskite Structures
}

\author{
Hassiba Messaoudi ${ }^{1,4, *}$, Sébastien Thomas ${ }^{2}$, Samira Slyemi $^{1}$, Abdelhamid Djaidja ${ }^{1,3}$, \\ Akila Barama ${ }^{1}$
}

${ }^{1}$ Laboratoire des Matériaux Catalytiques et Catalyse en Chimie Organique, Faculté de Chimie, Université des Sciences et de la Technologie Houari Boumediene, BP 32 El Alia, 16111Bab Ezzouar, Alger, Algeria.

Institut de Chimie et Procédés pour l'Énergie, l'Environnement et la Santé, UMR 7515 CNRS-Université de Strasbourg, Groupe "Énergies et Carburants pour un Environnement durable”, 25 rue Becquerel, 67087 Strasbourg Cedex 2, France.

${ }^{3}$ Laboratoire des Procédés pour Matériaux, Energie, Eau et Environnement, Faculté des Sciences et des Sciences Appliquées, Université de Bouira, rue Drissi Yahia, 10000 Bouira, Algeria.

${ }^{4}$ Faculté des Sciences, Département Sciences de la Matière, Université d'Alger 1, 2 Rue Didouche Mourad, Alger centre 16000, Alger, Algeria.

Received: $1^{\text {st }}$ November 2020; Revised: $18^{\text {th }}$ December 2020; Accepted: $19^{\text {th }}$ December 2020; Available online: 26 th December 2020; Published regularly: December 2020

\begin{abstract}
In this paper, the catalytic properties of La-Ni-M $(\mathrm{M}=\mathrm{Co}, \mathrm{Cu})$ based materials in dry reforming of methane (DRM) for syngas $\left(\mathrm{CO}+\mathrm{H}_{2}\right)$ production, were studied in the temperature range $773-1073 \mathrm{~K}$. The $\mathrm{LaNi}_{0.9} \mathrm{M}_{0.1} \mathrm{O}_{3}$ and $\mathrm{La}_{2} \mathrm{Ni}_{0.9} \mathrm{M}_{0.1} \mathrm{O}_{4}(\mathrm{M}=\mathrm{Co}, \mathrm{Cu}$ and $\mathrm{Ni} / \mathrm{M}=0.9 / 0.1)$ catalysts were prepared by partial substitution of $\mathrm{Ni}$ by $\mathrm{Co}$ or $\mathrm{Cu}$ using sol-gel method then characterized by XRD, $\mathrm{H}_{2}$-TPR and $\mathrm{N}_{2}$ physisorption. The XRD analysis of fresh catalysts showed, in the case of Co-substitution, the formation of La-Ni and La-Co perovskite and spinel structures, while only $\mathrm{LaNiO}_{3}$ and $\mathrm{La}_{2} \mathrm{NiO}_{4}$ phases were observed for the $\mathrm{Cu}$-substituted samples. The substitution of these two structures by copper decreases the reduction temperature compared to cobalt. The reactivity results showed that the partial substitution of nickel by copper decreases the methane activation temperature, whereas a better stability of catalytic activity and syngas production was obtained via the cobalt-substituted catalysts, which is due to a synergistic effect between $\mathrm{Ni}$ and Co. The TPO analysis carried out on the spent catalysts indicated that the lowest carbon deposition was obtained for the cobalt substituted samples. Copyright ( $) 2020$ BCREC Group. All rights reserved
\end{abstract}

Keywords: Perovskite; Spinel; Transition metals; Dry reforming; Syngas

How to Cite: Messaoudi, H., Thomas, S., Slyemi, S., Djaidja, A., Barama, A. (2020). Syngas Production via Methane Dry Reforming over La-Ni-Co and La-Ni-Cu Catalysts with Spinel and Perovskite Structures. Bulletin of Chemical Reaction Engineering \& Catalysis, 15(3), 885-897 (doi:10.9767/bcrec.15.3.9295.885-897)

Permalink/DOI: https://doi.org/10.9767/bcrec.15.3.9295.885-897

\section{Introduction}

Syngas $\left(\mathrm{H}_{2}+\mathrm{CO}\right)$ is an essential raw material for several reactions in the petrochemical indus-

* Corresponding Author.

Email: messaoudihassiba@gmail.com (H. Messaoudi); try, especially for the production of higher hydrocarbons [1]. The syngas is principally provided via the methane reforming through one of the three processes [2-4], i.e. steam reforming, partial oxidation and dry reforming by $\mathrm{CO}_{2}$. Among these processes, the dry reforming of methane (DRM) is considered the most promis- 
ing reaction since it allows at the same time the conversion of methane into synthesis gas (with an equimolar ratio $\mathrm{H}_{2} / \mathrm{CO}$ ) by using $\mathrm{CO}_{2}$ (greenhouse gas) which also contributes to the reduction of this gas emissions in the environment [5].

$$
\mathrm{CH}_{4}+\mathrm{CO}_{2} \leftrightarrow 2 \mathrm{CO}+2 \mathrm{H}_{2} \Delta \mathrm{H}^{\circ}{ }_{298 \mathrm{~K}}=+247 \mathrm{~kJ} / \mathrm{mol}
$$

The DRM process requires high energy because it is a highly endothermic reversible reaction [6]. Indeed, a very high temperature is necessary for the course of the reaction and the formation of synthesis gas as the main product of this reaction [7]. In this case, the purpose of using catalysts is to reduce the energy required to obtain a high yield of syngas.

However, like all the other catalytic processes which are carried out at high temperature, the DRM reaction is also confronted with problems of catalysts deactivation due to sintering and carbon deposition phenomena [8]. In fact, these problems cannot be completely avoided because they are linked to thermodynamics at high temperatures at which the reaction is performed. Whereas, these phenomena can be limited by bringing about changes in the operating conditions of the reaction or even on the structure and properties of the used catalysts [9].

Diverse catalytic systems are used in the DRM reaction in particular nickel supported catalysts [10] because of their high efficiency and low cost compared to noble metal catalysts [11]. Otherwise, the use of well-defined structures in methane reforming reactions is getting a lot of attention and is currently considered as one of the interesting alternative materials to minimize the problems of sintering and rapid deactivation of catalysts encountered with conventional supported nickel-based systems [12-14]. Indeed, the insertion of the nickel into a defined structure like spinel and perovskite has several advantages such as a well dispersion of nickel particles, a strong interaction that makes the nickel species less mobile than on the surface of a conventional support and furthermore a favored regeneration of nickel metallic sites by an in situ reduction. These properties should therefore improve the catalytic activity and stability of nickel species by limiting the formation of large aggregates and consequently reducing the coke deposition. Guo et al. [15] found that the $\mathrm{Ni} / \mathrm{MgO}-\gamma \mathrm{Al}_{2} \mathrm{O}_{3}$ and $\mathrm{Ni} / \mathrm{MgAl}_{2} \mathrm{O}_{4}$ catalysts tested in the dry reforming of methane exhibit better stability and higher activity compared to $\mathrm{Ni} / \gamma \mathrm{Al}_{2} \mathrm{O}_{3}$ system. In the one hand, these good catalytic performances were attributed to the formation of
$\mathrm{MgAl}_{2} \mathrm{O}_{4}$ spinel in $\mathrm{Ni} / \mathrm{MgO}-\gamma \mathrm{Al}_{2} \mathrm{O}_{3}$, which stabilizes small $\mathrm{Ni}$ crystallites. On the other hand, the high activity of the $\mathrm{Ni} / \mathrm{MgAl}_{2} \mathrm{O}_{4}$ catalyst compared to $\mathrm{Ni} / \gamma \mathrm{Al}_{2} \mathrm{O}_{3}$ were mainly related to the characteristics of the $\mathrm{MgAl}_{2} \mathrm{O}_{4}$ spinel support, that reduces the sintering phenomena of nickel active phase. In addition, according to these authors, the formation of $\mathrm{NiAl}_{2} \mathrm{O}_{4}$ is completely avoided over $\mathrm{MgAl}_{2} \mathrm{O}_{4}$ spinel phase and that strong interactions between nickel and $\mathrm{MgAl}_{2} \mathrm{O}_{4}$ produce highly dispersed active $\mathrm{Ni}$ species leading to high catalytic reactivity [15].

Other studies reported that $\mathrm{La}$ and $\mathrm{Ni}$ spinel and perovskite structures were found to be very interesting catalysts in the DRM reaction because of the uniform dispersion of $\mathrm{Ni}$ thus reducing $\mathrm{Ni}^{0}$ segregation and the generated $\mathrm{La}_{2} \mathrm{O}_{3}$ that interact with $\mathrm{CO}_{2}$ to form $\mathrm{La}_{2} \mathrm{O}_{2} \mathrm{CO}_{3}$ intermediates, which help to decrease coke formation [16-18]. Furthermore, it has been confirmed in our previous work, that the use of $\mathrm{MgAl}_{2} \mathrm{O}_{4}$ spinel as catalytic support for the $\mathrm{LaNiO}_{3}$ and $\mathrm{La}_{2} \mathrm{NiO}_{4}$ catalysts increases the $\mathrm{CH}_{4}$ and $\mathrm{CO}_{2}$ conversions and enhanced the catalytic stability [3].

In order to further improve the catalytic activity and the metal dispersion, the effect of nickel doping with another transition metal has also been the subject of many studies. Indeed, these bimetallic systems have exhibited very good catalytic performances [19-21] due to the synergistic effect between the nickel and the inserted metal, which contributes to the improvement of the activity and stability of the final catalyst. In a study on bimetallic catalysts, Fan et al. [22] compared the conversion rates of methane on $\mathrm{Ni} / \mathrm{MgO}-\mathrm{ZrO}_{2}, \mathrm{Co} / \mathrm{MgO}$ $\mathrm{ZrO}_{2}$, and $\mathrm{Ni}-\mathrm{Co} / \mathrm{MgO}-\mathrm{ZrO}_{2}$ catalysts. Bimetallic Ni-Co reached $80 \%$ methane conversion at $1023 \mathrm{~K}$, higher than those observed with monometallic catalysts $\mathrm{Ni}$ and $\mathrm{Co}(70 \%$ and $71 \%$, respectively). The increase of the catalytic activity of the bimetallic compound relative to the monometallic ones has been synonymous with the synergistic effect due to the coexistence of small particles of both $\mathrm{Ni}$ and the added metal. Another work developed by Nataj et al. [23] studied the effects of nickel and copper loadings and reaction temperature on the reactivity of $\mathrm{Ni}-\mathrm{Cu} / \mathrm{Al}_{2} \mathrm{O}_{3}$ catalysts in methane dry reforming. The results indicated that the catalytic activity was strongly influenced by the amounts of $\mathrm{Cu}$. Furthermore, sintering of active phases during the reaction was restricted by the formation of $\mathrm{Ni}-\mathrm{Cu}$ alloy that leads to the improvement of both catalyst activity and stability. However, the promoting effects of copper were significantly faded by increasing 
$\mathrm{Cu}$ content. Samples with high amounts of copper presented lower activity and rapid deactivation due to the agglomeration of active phase and Ni covering.

In this context, the present work is focused on the study of the catalytic performances of Ni-M bimetallic materials $(\mathrm{M}=\mathrm{Co}, \mathrm{Cu})$ of welldefined perovskite and spinel structures in the methane dry methane reaction for the production of synthesis gas. The bimetallic catalysts were prepared by the substitution of $10 \mathrm{~mol} \%$ of $\mathrm{Ni}$ by cobalt or copper in the monometallic structure $\mathrm{LaNiO}_{3}$ and $\mathrm{La}_{2} \mathrm{NiO}_{4}$.

\section{Materials and Methods}

\subsection{Catalysts Preparation}

Non substituted La-Ni and substituted LaNi-M $(\mathrm{M}=\mathrm{Co}, \mathrm{Cu})$ with spinel and perovskite structures were prepared by the sol-gel method using nitrates salts and citric acid as raw materials [24]. The non substituted samples are perovskite $\mathrm{LaNiO}_{3}$ (noted LN3) and spinel $\mathrm{La}_{2} \mathrm{NiO}_{4}$ (noted LN4). While the nickel substituted solids by copper or cobalt are perovskite $\mathrm{LaNi}_{0.9} \mathrm{M}_{0.1} \mathrm{O}_{3}$ (noted LNM3) and spinel $\mathrm{La}_{2} \mathrm{Ni}_{0.9} \mathrm{M}_{0.1} \mathrm{O}_{4}$ (noted LNM4) with $\mathrm{M}=\mathrm{Co}, \mathrm{Cu}$. The corresponding loadings for $\mathrm{Co}$ and $\mathrm{Cu}$, respectively are $2.4 \mathrm{wt} \%$ and $2.5 \mathrm{wt} \%$ in the LNM3 samples and $1.5 \mathrm{wt} \%$ and $1.6 \mathrm{wt} \%$ in the LNM4 solids.

The preparation consists of dissolving the nitrate salts $\mathrm{La}\left(\mathrm{NO}_{3}\right)_{3} \cdot 6 \mathrm{H}_{2} \mathrm{O}$, and $\mathrm{Z}\left(\mathrm{NO}_{3}\right)_{2} \cdot 6 \mathrm{H}_{2} \mathrm{O}$ $(\mathrm{Z}=\mathrm{Ni}, \mathrm{Co}, \mathrm{Cu})$ in $10 \mathrm{~mL}$ of deionized water, according to the stoichiometric ratios of perovskite and spinel structures. The citric acid is then added with a molar ratio of citrate to metallic ions equal to 3.0. The resulting solution is left under stirring and heating at $353 \mathrm{~K}$ until a green gel is obtained which is dried at $393 \mathrm{~K}$ for 12 hours. The final precursors were calcined at $1023 \mathrm{~K}\left(5 \mathrm{~K} \cdot \mathrm{min}^{-1}\right)$ for 6 hours in the case of the perovskite and 4 hours for the spinel. The calcination conditions were fixed after several tests of heat treatments during different times and at various temperatures in order to obtain high crystallinity under moderately severe conditions.

\subsection{Catalysts Characterization}

\subsubsection{Powder X-Ray diffraction (XRD)}

The structure of the fresh, reduced and used catalysts was studied by the X-Ray diffraction analysis using a Bruker AXS-D8 diffractometer with a $\mathrm{Cu}-\mathrm{K} \alpha$ radiation $(\lambda=1.5406 \AA)$. The XRD patterns were recorded in a $2 \theta$ range of $10-80^{\circ}$ with a step size of $0.020^{\circ}$ and a time of $0.80 \mathrm{~s}$ per step. The phase composition was determined using powder files (PDF-ICDD).

\subsubsection{Surface area measurements (BET)}

The specific surface areas of the different samples were obtained by measuring nitrogen adsorption-desorption isotherms at $77 \mathrm{~K}$ using a Micromeritics ASAP 2420 instrument. Prior to measurements, around $100 \mathrm{mg}$ of sample were outgassed under vacuum at $523 \mathrm{~K}$ for 12 $\mathrm{h}$. The BET surface areas were calculated with the Brunauer, Emmett and Teller model in the range of $P / P_{0}$ of $0.05-0.30$. The pore size distribution was determined using the BarrettJoyner-Halenda (BJH) method.

\subsubsection{Temperature programmed reduction $\left(\mathrm{H}_{2}-\right.$} TPR)

The reducibility of the catalysts was studied by the temperature programmed reduction $\left(\mathrm{H}_{2}\right.$ TPR) on a Micromeritics Auto ChemII 2920 apparatus. The catalyst (around $50 \mathrm{mg}$ ) was heated from room temperature to $1173 \mathrm{~K}$ (10 K. $\mathrm{min}^{-1}$ ) under a flow of $10 \% \mathrm{H}_{2}$ in argon (50 mLsatr. $\left.\mathrm{min}^{-1}\right)$. The reduction temperatures, the $\mathrm{H}_{2}$-consumption as well as the reduction degree (called '\% red') of the different samples were measured by this technique. The \% red designates the ratio between the number of moles of experimental and theoretical $\mathrm{H}_{2}$ consumed by the sample.

\subsubsection{Temperature programmed oxidation} (TPO)

The analysis of the carbon deposits on the surface of spent samples (after catalytic test in DRM) was carried out by TPO analysis coupled to a mass spectrometer with a Pfeiffer Vacuum instrument QMS 2000 Prisma. Around $10 \mathrm{mg}$ of used sample were subjected to a flow of heli-

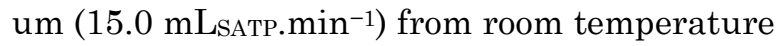
to $1073 \mathrm{~K}\left(15 \mathrm{~K} \cdot \mathrm{min}^{-1}\right)$ to desorb the carbonates. After cooling to $323 \mathrm{~K}$, the TPO was carried out under $1.0 \% \mathrm{~mol} \mathrm{O}_{2}$ in $\mathrm{He}(15.0$ mLsATP. min $^{-1}$ ) up to $1073 \mathrm{~K}$ with a temperature ramp of $8 \mathrm{~K} \cdot \mathrm{min}^{-1}$.

\subsection{Catalytic reaction}

Catalytic tests in methane dry reforming using a molar ratio $\mathrm{CH}_{4} / \mathrm{CO}_{2}=1.0$ (Figure 1) were conducted at atmospheric pressure using a quartz reactor in form I (length $300 \mathrm{~mm}$, inner diameter $7.0 \mathrm{~mm}$ ) placed in an experimental setup previously described [4], in the temperature range $773-1073 \mathrm{~K}$. The catalyst $(15.0 \mathrm{mg})$ was pretreated under nitrogen from 
room temperature to $773 \mathrm{~K}\left(3.0 \mathrm{~mL}\right.$ SATP. $\left.\mathrm{min}^{-1}\right)$ then the gas mixture is introduced at rate of 28.0 mLSATP. $\mathrm{min}^{-1}$ (GHSV around $5.6 \times 10^{4} \mathrm{~h}^{-1}$ ). The equations used to calculate conversions of $\mathrm{CH}_{4}, \mathrm{CO}_{2}$ and yields of $\mathrm{H}_{2}, \mathrm{CO}$ are given below [3]:

Conversion of $\mathrm{CH}_{4}=\mathrm{X}_{\mathrm{CH}_{4}}=\frac{F_{\text {in }\left(\mathrm{CH}_{4}\right)}-F_{\text {out }\left(\mathrm{CH}_{4}\right)}}{F_{\text {in }\left(\mathrm{CH}_{4}\right)}}$

Conversion of $\mathrm{CO}_{2}=X_{\mathrm{CO}_{2}}=\frac{F_{i n\left(\mathrm{CO}_{2}\right)}-F_{\text {out }\left(\mathrm{CO}_{2}\right)}}{F_{i n\left(\mathrm{CO}_{2}\right)}}$

Yield of $\mathrm{H}_{2}=Y_{\mathrm{H}_{2}}=\frac{F_{\text {out }\left(\mathrm{H}_{2}\right)}}{2 \times F_{\text {in }\left(\mathrm{CH}_{4}\right)}}$

Yield of $\mathrm{CO}=Y_{\mathrm{CO}}=\frac{F_{\text {out }(\mathrm{CO})}}{F_{\text {in }\left(\mathrm{CH}_{4}\right)}+F_{\text {in }\left(\mathrm{CO}_{2}\right)}}$

where $F_{\text {in }}$ is the inlet molar flow and $F_{\text {out }}$ is the outlet molar flow.

\section{Results and Discussion}

\subsection{Catalysts Characterizations}

The BET surface areas and the average pore diameters of the calcined samples are reported in Table 1. It can be seen that for all samples, average pore diameters around $5 \mathrm{~nm}$ were obtained indicating a mesoporous texture of our solids. The elaborated samples also revealed very low specific surfaces between $5-7 \mathrm{~m}^{2} \cdot \mathrm{g}^{-1}$, which evidences that the partial substitution of nickel by cobalt or copper on both perovskite and spinel structures has no significant effect on the evolution of the BET surface. Indeed, these results are also similar to those reported by Valderrama et al. [25], who studied the texture of $\mathrm{LaNiO}_{3}$ and $\mathrm{LaNi}_{0.8} \mathrm{Co}_{0.2} \mathrm{O}_{3}$ cobalt-type perovskite catalysts, calcined at $1023 \mathrm{~K}$. These authors have measured specific surfaces of the order of $7 \mathrm{~m}^{2} \cdot \mathrm{g}^{-1}$ for both catalysts. The nitrogen adsorption-desorption isotherms of the calcined samples, shown in Figure 2-a, are similar to type IV (IUPAC classification [26]) characteristic of mesoporous materials $(2-50 \mathrm{~nm})$, which agrees with the obtained pore diameter (around $5 \mathrm{~nm}$ ). The pore size distribution represented by the BJH curves (Figure 2-b) also confirms the mesoporous character of the elaborated samples with a porous distribution between 2 and $10 \mathrm{~nm}$.

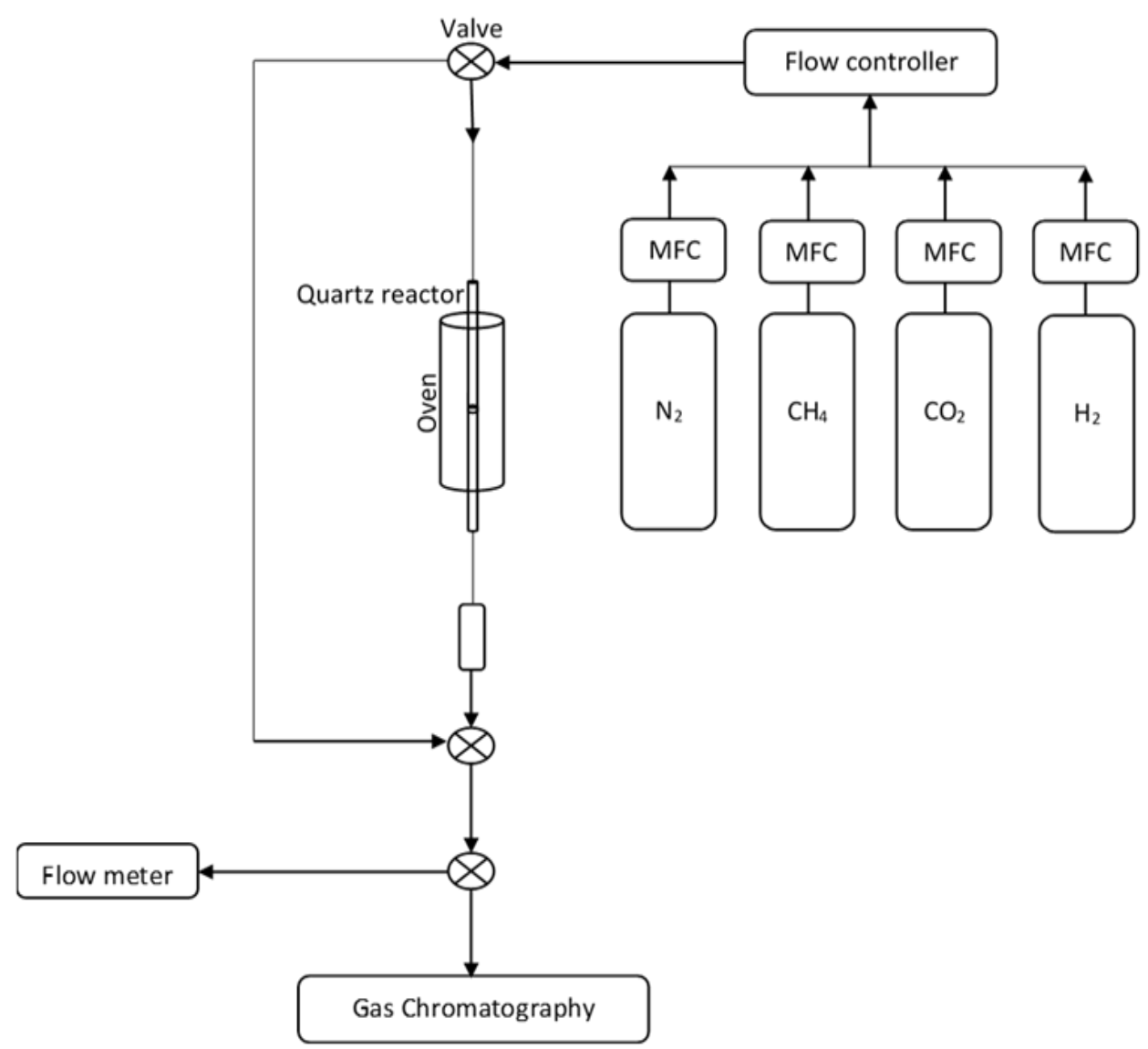

Figure 1. Experimental set up of methane dry reforming. 


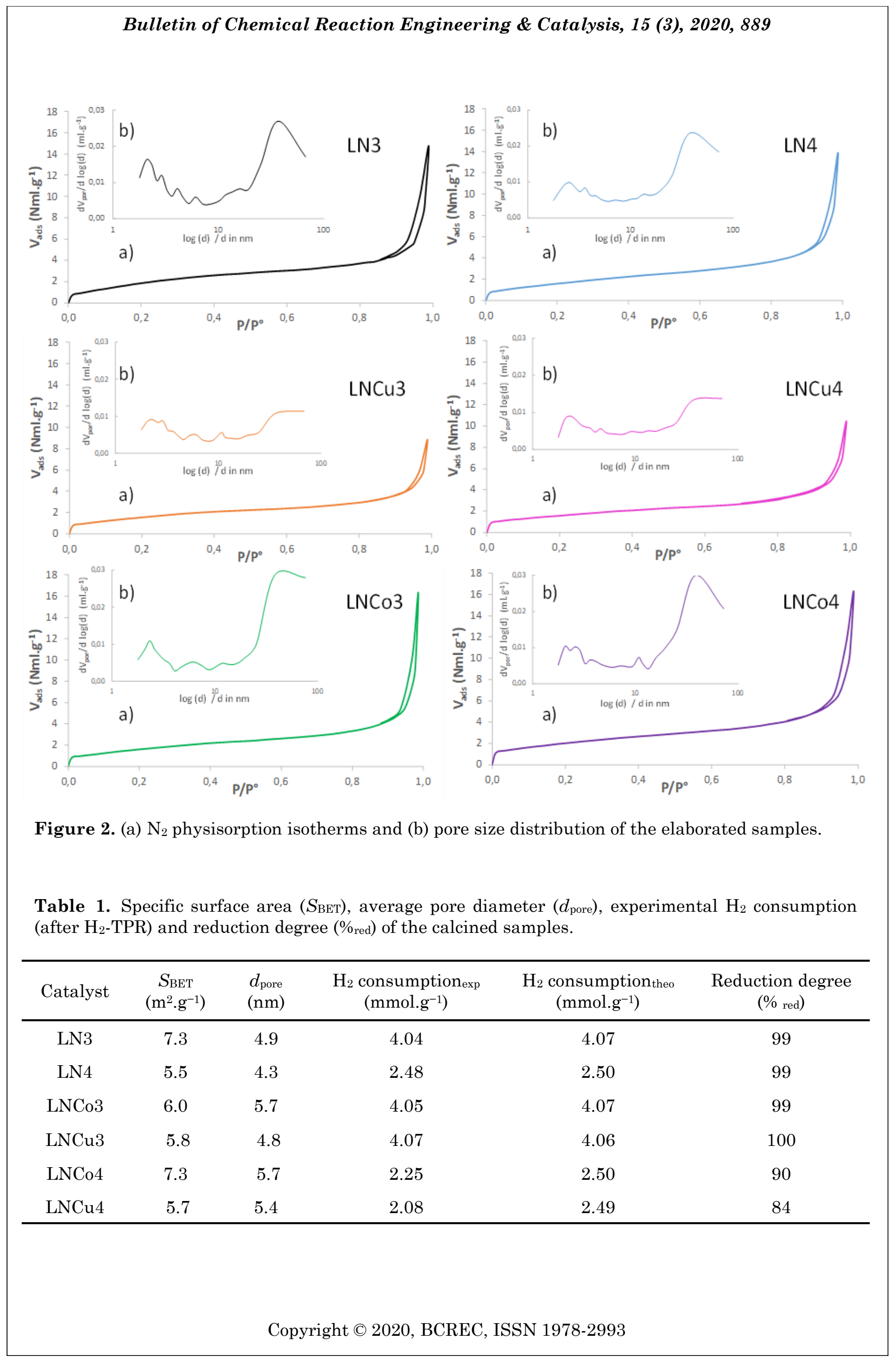


Figure 3 shows the XRD patterns of the different fresh catalysts. The diffractogram of non-substituted perovskite $\mathrm{LaNiO}_{3}$ and spinel $\mathrm{La}_{2} \mathrm{NiO}_{4}$ structures obtained in our previous work [3] are also given as references. As can be seen from the XRD results, the substitution of nickel in perovskite and spinel structures by cobalt or copper affects the crystalline structure. In the case of fresh $\mathrm{LNCo} 3$ and $\mathrm{LNCu} 3$ samples calcined at $1023 \mathrm{~K}$, the diffractograms reveal the formation of perovskite phases, on the contrary $\mathrm{LNC} 04$ and $\mathrm{LNCu} 4$ which present the formation of mixture of spinel phase and lanthanum oxide $\mathrm{La}_{2} \mathrm{O}_{3}$ (PDF-ICDD 05-0602) with a predominant of $\mathrm{La}_{2} \mathrm{O}_{3}$ in the case of the cobalt-substituted solid. It is also important to point out that it is difficult to accurately determine the spinel and perovskite phases formed in the case of cobalt-substituted samples. Indeed, an overlap between the diffraction lines of $\mathrm{LaNiO}_{3}$ (PDF-ICDD 33-0711) and $\mathrm{LaCoO}_{3}$ (PDF-ICDD 48-0123) was observed for $\mathrm{LNCo} 3$ and between those of $\mathrm{La}_{2} \mathrm{NiO}_{4}$ (PDF-ICDD 340314) and $\mathrm{La}_{2} \mathrm{CoO}_{4}$ (PDF-ICDD 72-0937) for LNCo4. These overlap phenomena were also observed by G. Valderrama et al. when substituting $\mathrm{Ni}$ by Co with a substitution ratio ranging from 0 to 1 [25]. On the other hand, the substitution of both perovskite and spinel structures by copper gives rise to the formation of $\mathrm{LaNiO}_{3}$ and $\mathrm{La}_{2} \mathrm{NiO}_{4}$ phases. No copper based phase was identified. According to the literature, the absence of copper phase or $\mathrm{Ni}$ $\mathrm{Cu}$ alloy in the case of $\mathrm{Cu}$-substituted samples can be explained by a good dispersion of copper species in the calcined sample [27-28].

To examine the effect of $\mathrm{H}_{2}$-reduction on the structure of our materials, samples after $\mathrm{H}_{2}$ TPR analysis were also characterized by XRD (Figure 4). The diffractograms show the presence of $\mathrm{La}_{2} \mathrm{O}_{3}$ phase accompanied by the characteristic peaks of metallic nickel $\mathrm{Ni}^{0}$ (PDFICDD 04-0850) for both LNM3 and LNM4 structures. No characteristic peak of metallic cobalt or copper has been detected which may be due to their very low content and /or their good dispersion. We also note the absence of alloy between nickel and cobalt or copper which is confirmed by the $\mathrm{H}_{2}$-TPR analysis (Figure 5) that highlighted two reduction peaks attribut-
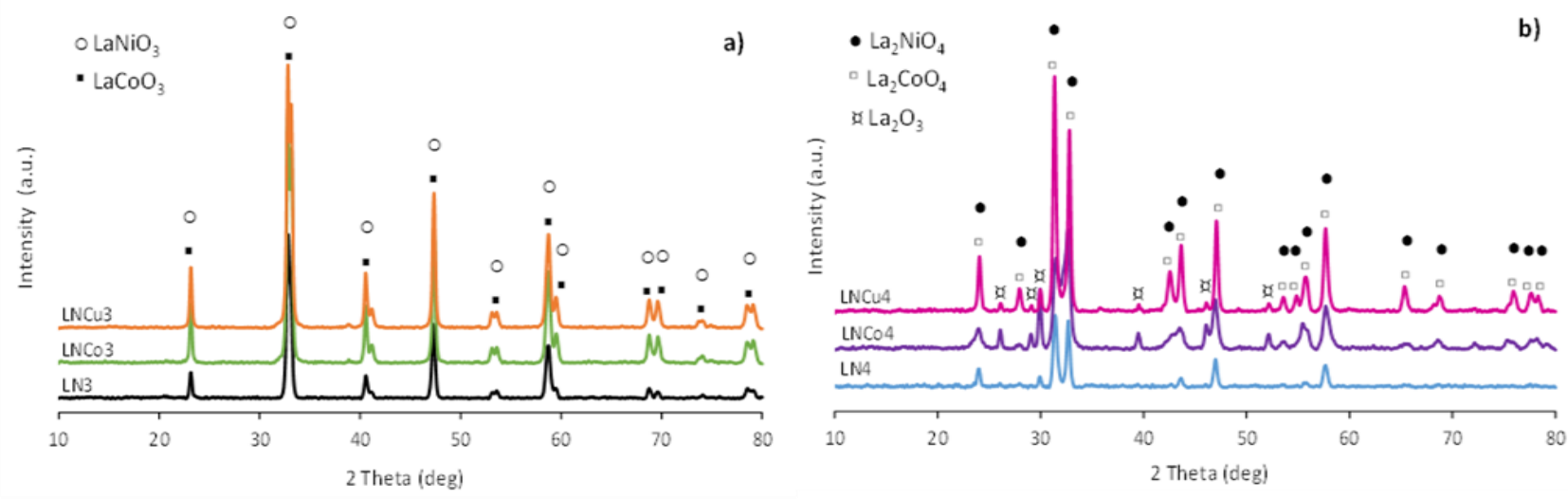

Figure 3. XRD patterns of fresh catalysts: a) LNM3 and b) LNM4 $(\mathrm{M}=\mathrm{Co}, \mathrm{Cu})$.
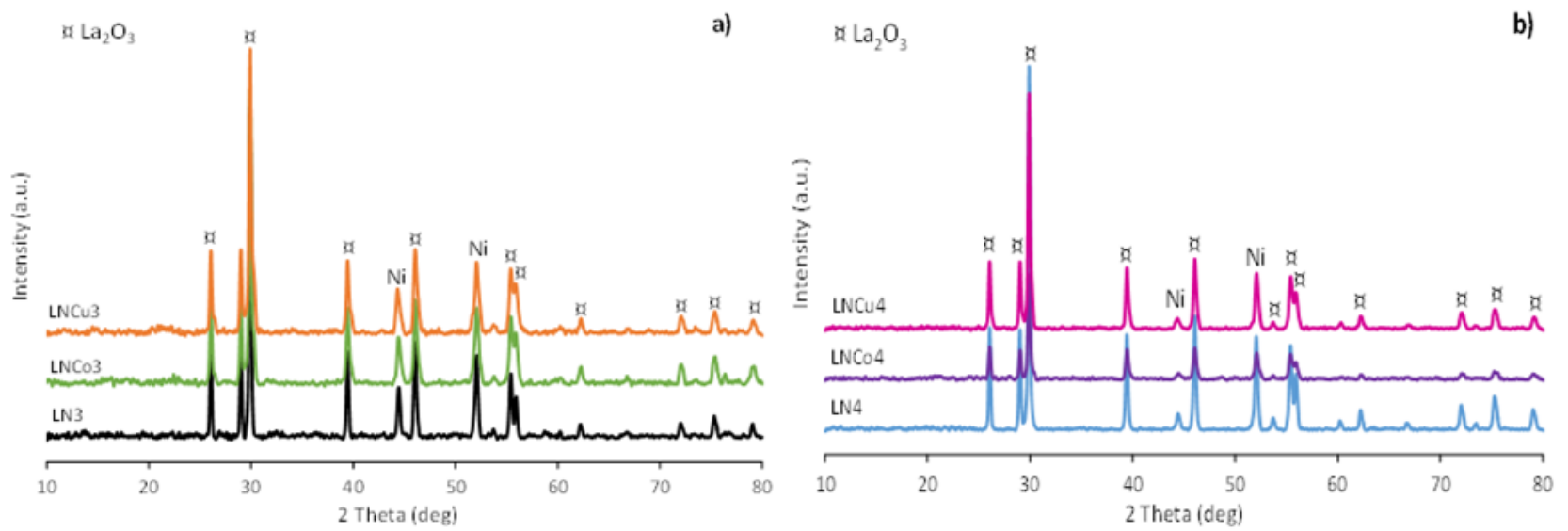

Figure 4. XRD patterns of the samples after $\mathrm{H}_{2}$-TPR analysis: a) LNM3 and b) LNM4 $(\mathrm{M}=\mathrm{Co}, \mathrm{Cu})$. 
ed to the reduction of $\mathrm{Ni}^{2+}$. Indeed, according to the literature works $[26,29]$, the alloy formation is confirmed by the presence of a single reduction peak indicating that the reduction of bimetallic catalysts (Ni-Co) occurs in one step.

The $\mathrm{H}_{2}$-TPR profiles of the elaborated LNM3 and LNM4 catalysts are represented in Figure 5. In order to highlight the effect of nickel substitution by cobalt or copper on the reducibility, the profiles of non-substituted spinel $\mathrm{La}_{2} \mathrm{NiO}_{4}$

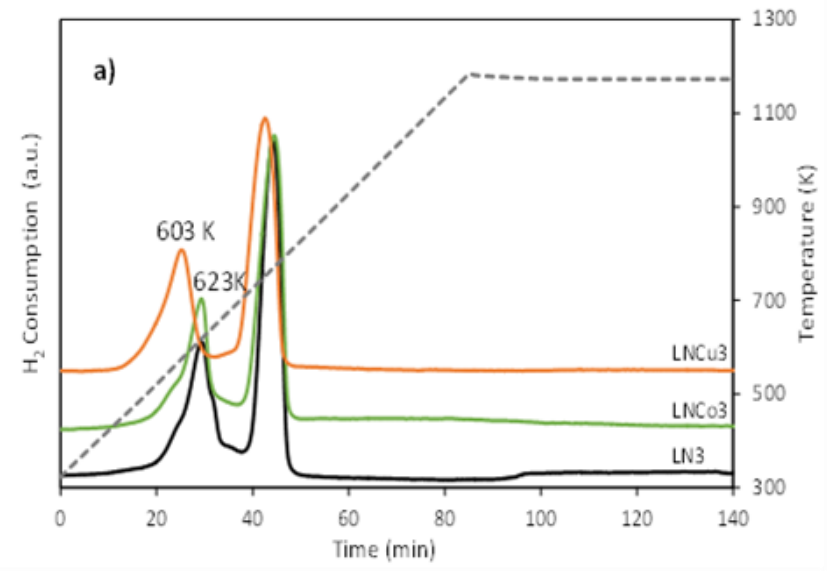

and perovskite $\mathrm{LaNiO}_{3}$ samples are also given. For all samples, two reduction peaks are observed. For LNM3 sample, the first one corresponds to the reduction of $\mathrm{Ni}^{3+}$ to $\mathrm{Ni}^{2+}$ in $\mathrm{La}_{2} \mathrm{Ni}_{2} \mathrm{O}_{5}\left(2 \mathrm{LaNiO}_{3}+\mathrm{H}_{2} \rightarrow \mathrm{La}_{2} \mathrm{Ni}_{2} \mathrm{O}_{5}+\mathrm{H}_{2} \mathrm{O}\right)$ and also to that of $\mathrm{NiO}$ species, while for LNM4 solid, it represents the reduction of $\mathrm{NiO}$ to $\mathrm{Ni}^{0}$. Concerning the second peak, it is attributed to the reduction of $\mathrm{Ni}^{2+}$ species present in form of $\mathrm{La}_{2} \mathrm{NiO}_{5}$ (in LNM3) and $\mathrm{La}_{2} \mathrm{NiO}_{4}$ (in LNM4) to

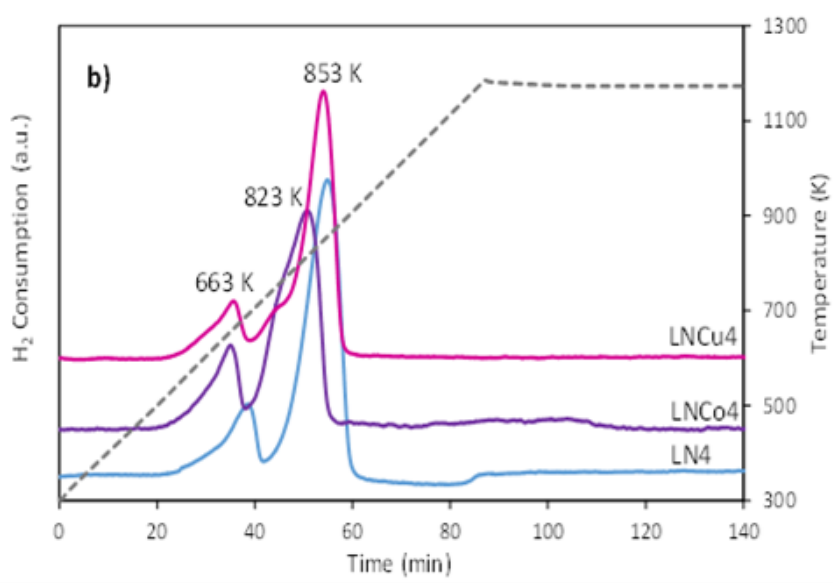

Figure 5. $\mathrm{H}_{2}$-TPR profiles of fresh catalysts: a) LNM3 and b) LNM4 $(\mathrm{M}=\mathrm{Co}, \mathrm{Cu})$.
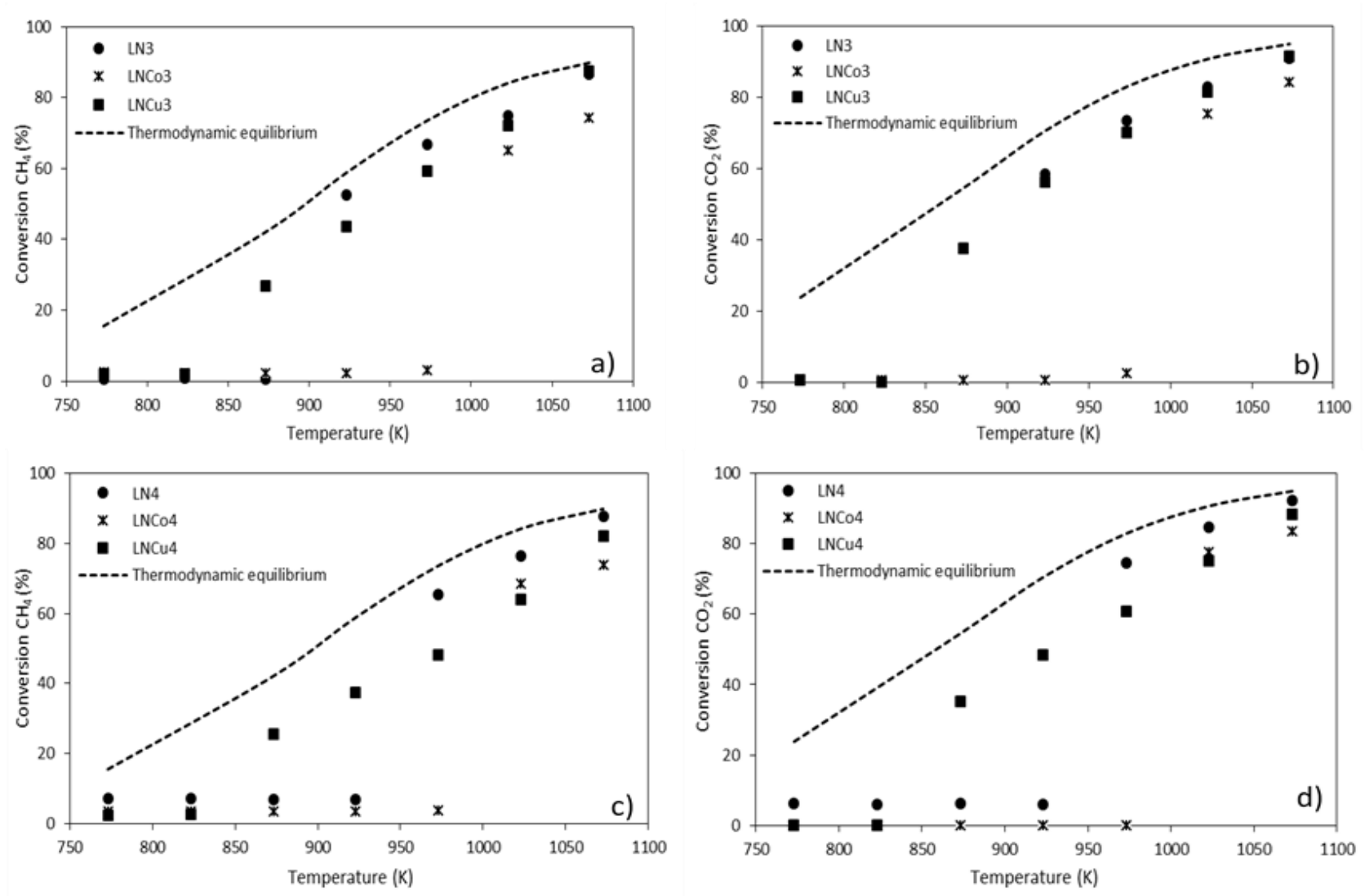

Figure 6. $\mathrm{CH}_{4}\left(\mathrm{a}\right.$ and $\mathrm{c}$ ) and $\mathrm{CO}_{2}(\mathrm{~b}$ and $\mathrm{d})$ conversions for the prepared catalysts $(\mathrm{W} / \mathrm{F}=0.0089$ g.h.L $\left.\mathrm{L}^{-1}, \mathrm{CH}_{4} / \mathrm{CO}_{2}=1.0\right)$ : LNM3 (a and b) and LNM4 (c and d) $(\mathrm{M}=\mathrm{Co}, \mathrm{Cu})$. Dotted lines : thermodynamics equilibrium. 
lanthanium oxide and metallic nickel as follows: $\mathrm{La}_{2} \mathrm{Ni}_{2} \mathrm{O}_{5}+2 \mathrm{H}_{2} \rightarrow 2 \mathrm{Ni}+\mathrm{La}_{2} \mathrm{O}_{3}+2 \mathrm{H}_{2} \mathrm{O}$ and $\mathrm{La}_{2} \mathrm{NiO}_{4}+\mathrm{H}_{2} \rightarrow \mathrm{La}_{2} \mathrm{O}_{3}+\mathrm{Ni}+\mathrm{H}_{2} \mathrm{O}$. The $\mathrm{LNCo} 3$ profile is similar to that of $\mathrm{LaNiO}_{3}$ perovskite sample. In the case of $\mathrm{LNCo} 4$, a $30 \mathrm{~K}$ decrease of temperature of both reduction peaks was noted (663 and $823 \mathrm{~K}$ for the substituted sample instead of $693 \mathrm{~K}$ and $853 \mathrm{~K}$ for the $\mathrm{La}_{2} \mathrm{NiO}_{4}$ oxide). On the contrary, for copper substituted samples, a significant decrease of temperature for the low temperature peak was observed for both structures compare to the non-substituted samples. Indeed, the first reduction peak is observed at $603 \mathrm{~K}$ for $\mathrm{LNCu} 3$ and at $668 \mathrm{~K}$ for $\mathrm{LNCu} 4$, which correspond to around $20 \mathrm{~K}$ temperature decrease compared to $\mathrm{LaNiO}_{3}$ and $25 \mathrm{~K}$ in comparison with $\mathrm{La}_{2} \mathrm{NiO}_{4}$ respectively. The second peak of reduction was recorded at $768 \mathrm{~K}$ for $\mathrm{LNCu} 3$ and $853 \mathrm{~K}$ for $\mathrm{LNCu} 4$ which is close to the temperature of the corresponding non substituted structure. According to Moradi et al. [28] and Nataj et al. [23], $\mathrm{Cu}^{2+}$ is reduced in $\mathrm{Cu}^{0}$ at temperatures lower than those corresponding to the reduction of $\mathrm{Ni}^{3+}$ and $\mathrm{Ni}^{2+}$, and that the presence of $\mathrm{Cu}^{0}$ crystallites facilitates the reducilibilty of nickel cations. The experimental $\mathrm{H}_{2}$ consumption and reduction degree (\%) given in Table 1 indicate that the substituted LNM3 samples are more reducible than LNM4 ones. Indeed, regardless the incorporated metal $(\mathrm{Co}, \mathrm{Cu})$, the reduction is almost total in the case of LNM3 while for substituted LNM4 structures, it is estimated at $90 \%$ for $\mathrm{LNCo} 4$ and $84 \%$ for $\mathrm{LNCu} 4$.

\subsection{Catalysts Reactivity}

The reactivity results of LN3, LN4, LNM3, LNM4 $(\mathrm{M}=\mathrm{Cu}$ or $\mathrm{Co})$ in the dry reforming of methane, obtained in the temperature range (773-1073 K), are presented in Figure 6. Firstly, it can be noted that the nickel substitution by cobalt or copper has a significant effect on the initial conversion temperature of both methane and carbon dioxide. Indeed, the substitution by cobalt delays the activation of $\mathrm{CH}_{4}$ contrary to copper for which, a decrease in the initial activation temperature $\left(T_{\text {init }}\right)$ is observed. Comparing the initial activation temperature of both reactants $\mathrm{CH}_{4}$ and $\mathrm{CO}_{2}$, the cobalt substituted samples $\mathrm{La}_{\mathrm{x}} \mathrm{Ni}_{0.9} \mathrm{Co}_{0.1} \mathrm{O}_{\mathrm{y}}(\mathrm{x}=1,2$ and $\mathrm{y}$ $=3,4)$ show an increase of $\mathrm{T}_{\text {init }}(1023 \mathrm{~K})$ com-
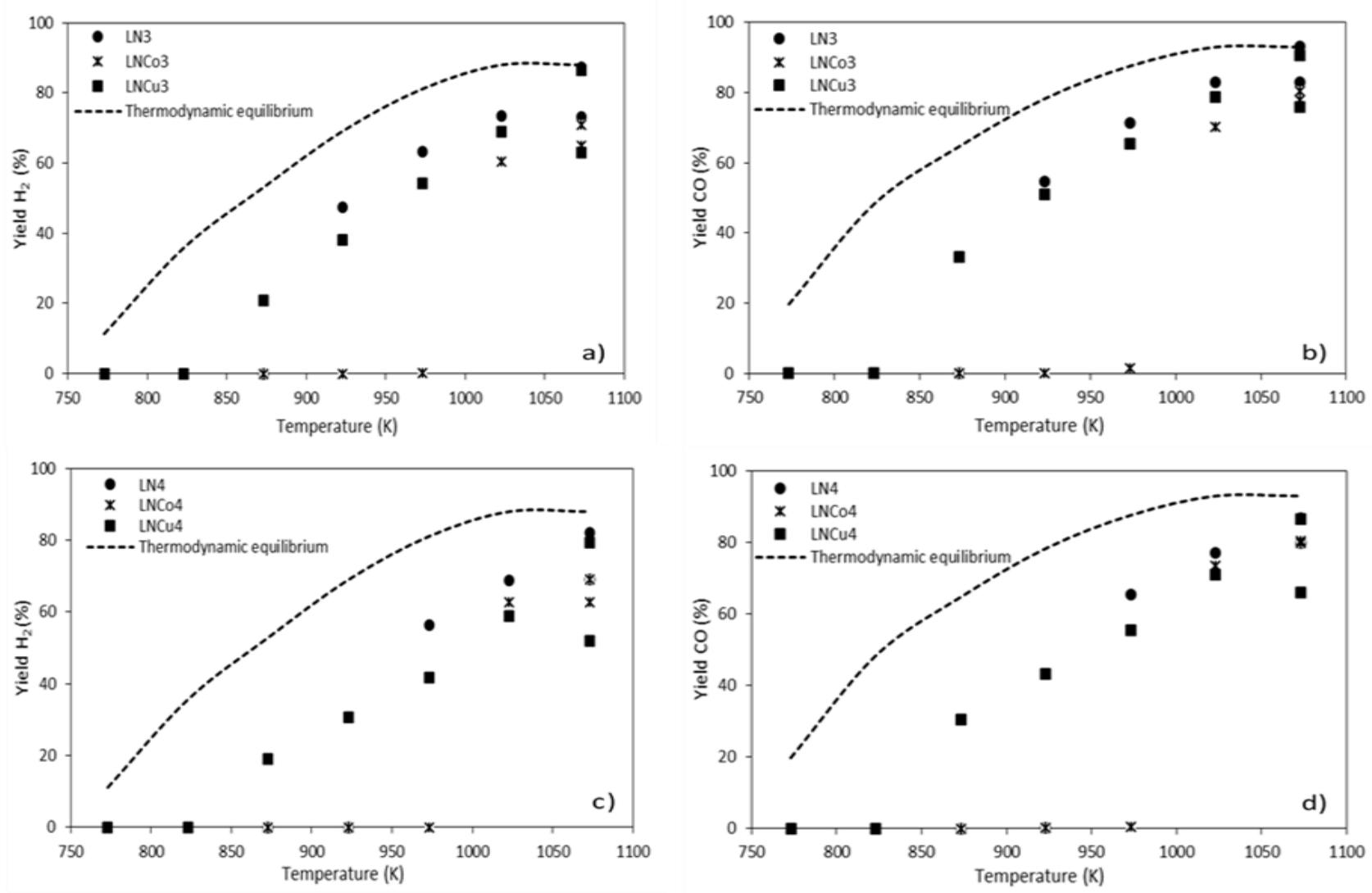

Figure 7: Yields of $\mathrm{H}_{2}$ (a and c) and $\mathrm{CO}\left(\mathrm{b}\right.$ and d) in dry reforming of methane (W/F $=0.0089$ g.h.L. $\mathrm{L}^{-1}$, $\left.\mathrm{CH}_{4} / \mathrm{CO}_{2}=1\right)$ : LNM3 (a and b) and LNM4 (c and d) $(\mathrm{M}=\mathrm{Co}, \mathrm{Cu})$. Dotted lines : thermodynamics equilibrium. 

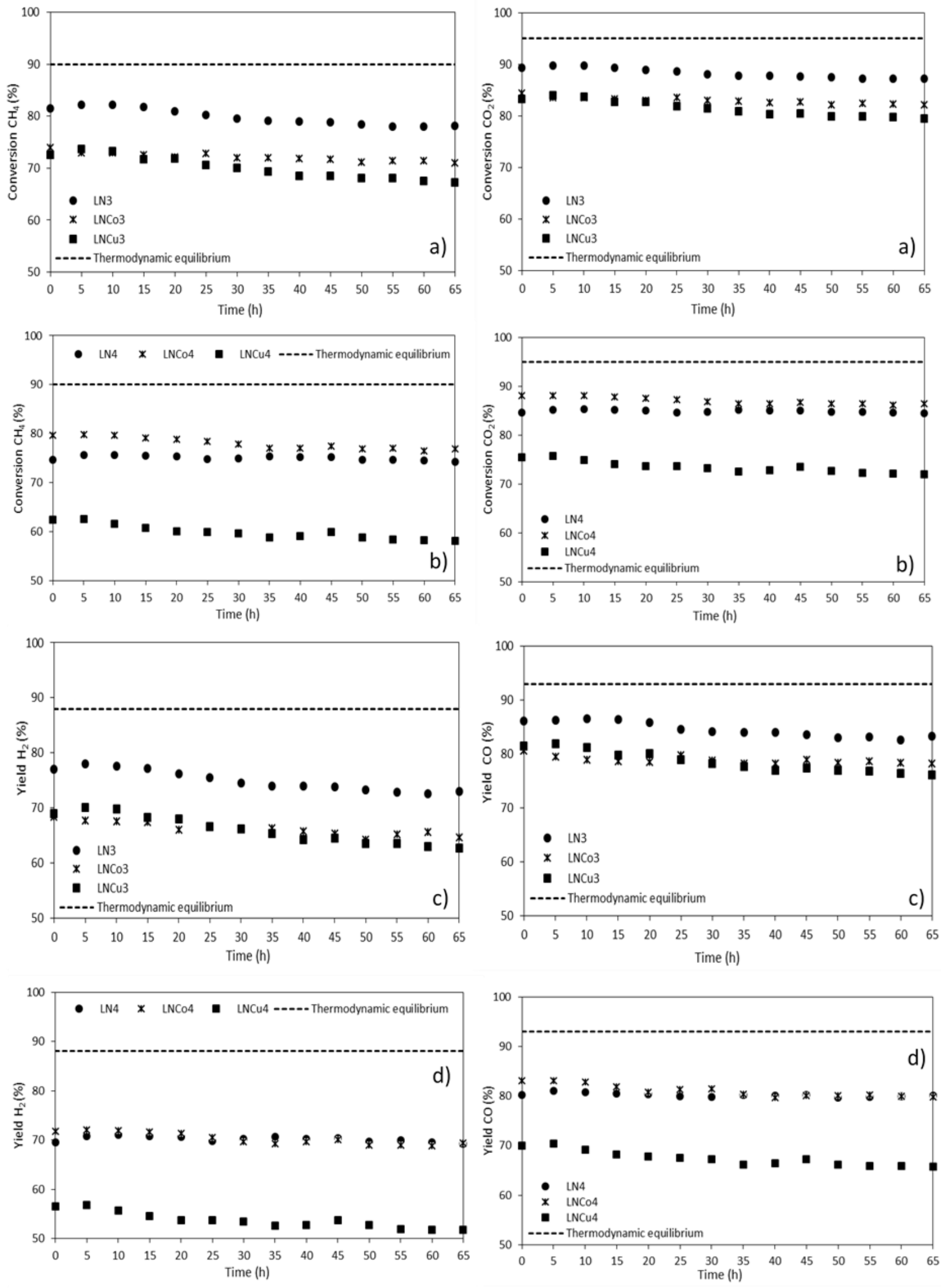

Figure 8. Stability results in DMR of the catalysts prepared by sol-gel method at $1073 \mathrm{~K}(\mathrm{~W} / \mathrm{F}=$ 0.0089 g.h.L $\left.\mathrm{L}^{-1}, \mathrm{CH}_{4} / \mathrm{CO}_{2}=1\right)$ : (a) \& (c) for LNM3 and (b) \& (d) for LNM4 $(\mathrm{M}=\mathrm{Co}, \mathrm{Cu})$. 
pared to the copper substituted catalyst $\mathrm{La}_{\mathrm{x}} \mathrm{Ni}_{0.9} \mathrm{Cu}_{0.1} \mathrm{O}_{\mathrm{y}}\left(T_{\text {init }}=873 \mathrm{~K}\right)$. At the reaction temperature of $1073 \mathrm{~K}$, the highest $\mathrm{CH}_{4}$ and $\mathrm{CO}_{2}$ conversions, estimated respectively at 88 and $91 \%$, are obtained over the copper substituted sample with spinel structure ( $\mathrm{LNCu} 4)$.

The decrease of the activation temperature of both reactants, observed in the case of copper substituted catalysts, can be explained by the formation of $\mathrm{Cu}^{0}$ crystallites that favors the reducibility of nickel cations to active metallic sites $\mathrm{Ni}^{0}$. Similar results have been observed by Valderrama et al. [25] for $\mathrm{LaCoO}_{3}$ catalyst and Moradi et al. [28] in the case of copper substituted catalysts.

The yields of reaction products $\left(\mathrm{CO}+\mathrm{H}_{2}\right)$ are shown in Figure 7. The measured yields at $1073 \mathrm{~K}$ revealed that the copper catalysts $\mathrm{LNCu} 3$ and $\mathrm{LNCu} 4$ have similar $\mathrm{CO}$ and $\mathrm{H}_{2}$ yields compared to those obtained for corresponding non-substituted LN3 and LN4 samples. No differences were observed between the two structures in the case of copper containing samples (90 and $86 \%$ for perovskite $\mathrm{LNCu} 3$ ) and (86 and $79 \%$ for spinel LNCu4). However, for the catalysts substituted by cobalt, a significant difference in the product yields is noted for the two structures compared to the nonsubstituted samples with a higher $\mathrm{CO} / \mathrm{H}_{2}$ ratio at the reactor outlet. This high ratio, indicating an important $\mathrm{CO}$ production, suggests the important participation of the reverse water gas (RWGS) reaction for the cobalt based catalysts [31].

The study of the effect of the reaction time on the stability of catalytic performances was carried out at $1073 \mathrm{~K}$ during $65 \mathrm{~h}$ of catalytic test (Figure 8). Results obtained on nonsubstituted LN3 and LN4 catalysts show that both catalysts exhibit relatively stable conversions of reactants $\left(76 \%\right.$ of $\mathrm{CH}_{4}$ and $86 \%$ of $\left.\mathrm{CO}_{2}\right)$ and product yields (around $70 \%$ of $\mathrm{H}_{2}$ and $80 \%$ of $\mathrm{CO}$ ) for both samples. However, it is also important to note that the spinel catalyst LN4 is slightly more stable over time than perovskite LN3. This difference in stability may be due to the presence of a larger amount of $\mathrm{La}_{2} \mathrm{O}_{3}$ in the spinel catalyst, on which $\mathrm{CO}_{2}$ can adsorb and then migrate in the bulk to form $\mathrm{La}_{2} \mathrm{O}_{2} \mathrm{CO}_{3}$ intermediate; this latter prevents carbon deposition and reduces the deactivation of active nickel species according to the following equation: $\mathrm{La}_{2} \mathrm{O}_{2} \mathrm{CO}_{3}+\mathrm{Ni}-\mathrm{C} \rightarrow \mathrm{La}_{2} \mathrm{O}_{3}+2 \mathrm{CO}+\mathrm{Ni}$ [32].

For the substituted catalysts, the obtained stability results show that the cobaltsubstituted samples with spinel structure (LNCo4) exhibit the best and most stable conversions $\left(\mathrm{CH}_{4}\right.$ and $\left.\mathrm{CO}_{2}\right)$ and syngas production $\left(\mathrm{H}_{2}+\mathrm{CO}\right)$, despite the fact that copper substituted samples activate the methane at lower temperature compared to the $\mathrm{Ni}$-Co catalysts. This better stability of cobalt-substituted catalysts could be explained by a synergistic effect between $\mathrm{Ni}$ and $\mathrm{Co}$ in the case of nickel-cobalt bimetallic catalysts [25,33-35]. In fact, the coexistence of these two metals contributes to the improvement of the catalytic performances and the stability of the catalysts.

In order to examine the structure evolution and coke deposition, XRD and TPO analyses were carried out on the spent catalysts after 65 $\mathrm{h}$ of catalytic test in DRM at $1073 \mathrm{~K}$. The XRD patterns (Figure 9) reveal a total decomposition of the initial phases and the appearance of characteristic peaks of $\mathrm{La}_{2} \mathrm{O}_{2} \mathrm{CO}_{3}$ (PDF-ICDD 048-1113) and $\mathrm{Ni}^{0}$ in addition to $\mathrm{La}_{2} \mathrm{O}_{3}$ phase. In fact, as previously mentioned, the formation of the $\mathrm{La}_{2} \mathrm{O}_{2} \mathrm{CO}_{3}$ phase is due to the in situ adsorption and bulk migration of $\mathrm{CO}_{2}$ [36]. Furthermore, no diffraction lines of copper, cobalt or carbon phases were detected for the spent
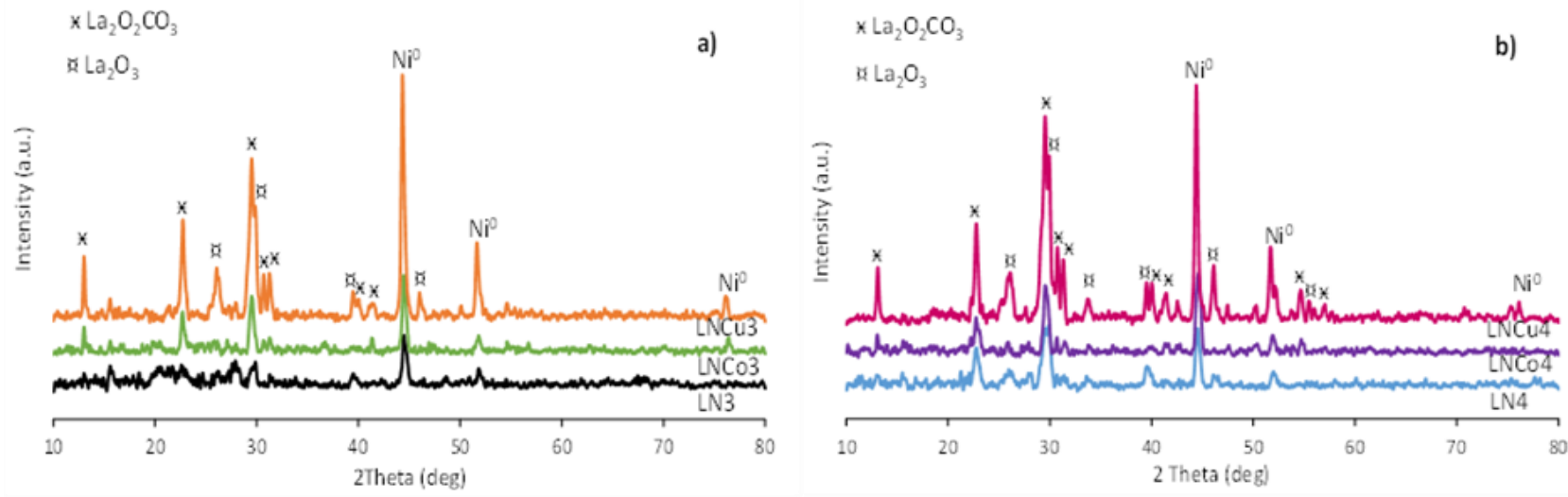

Figure 9: XRD of used catalysts calcined at $1023 \mathrm{~K}$ and temperature reaction $1023 \mathrm{~K}$ : a) LNM3 and b) LNM4 $(\mathrm{M}=\mathrm{Co}, \mathrm{Cu})$. 
samples, indicating no segregation of copper nor cobalt and no significant formation of structured carbon.

The TPO profiles (Figure 10) giving the oxygen consumption as a function of temperature, show for all the spent catalysts that the oxygen consumption occurred in the temperature range $833-973 \mathrm{~K}$ indicating the formation of $\mathrm{C}_{\gamma}$-type carbon due to the high reaction temperature and the long reaction time corresponding to nickel carbide $\mathrm{NiC}$ and/or carbon nanotubes [37-38].

The Measurements of carbon amounts deposited after $65 \mathrm{~h}$ of catalytic test in DRM were performed by TPO analysis. The obtained results reveal that the spinel $\mathrm{La}_{2} \mathrm{NiO}_{4}$ catalyst leads to low carbon formation (5.6 mmol.g $\left.{ }^{-1}\right)$ compared to $\mathrm{LaNiO}_{3}$ perovskite (13.3 mmol.g ${ }^{-1}$ ), which is in good agreement with the good stability of the $\mathrm{La}_{2} \mathrm{NiO}_{4}$ sample observed during the DRM reaction. The comparison between the cobalt and copper-substituted solids for the two structures shows that the substitution with cobalt leads to a carbon deposition of $8.2 \mathrm{mmol}^{-1}$ in the case of the perovskite LNCo3 and 9.9 mmol.g ${ }^{-1}$ for the spinel LNCo4. On the other hand, the presence of copper in the structure gives rise to amounts of 11.2 and 20.0 mmol.g ${ }^{-1}$ for $\mathrm{LNCu} 3$ and $\mathrm{LNCu} 4$ respectively. The lower carbon depositions obtained over the Co-substituted catalysts are in good agreement with the reactivity results that have revealed more stable catalytic performances in the case of cobalt samples.

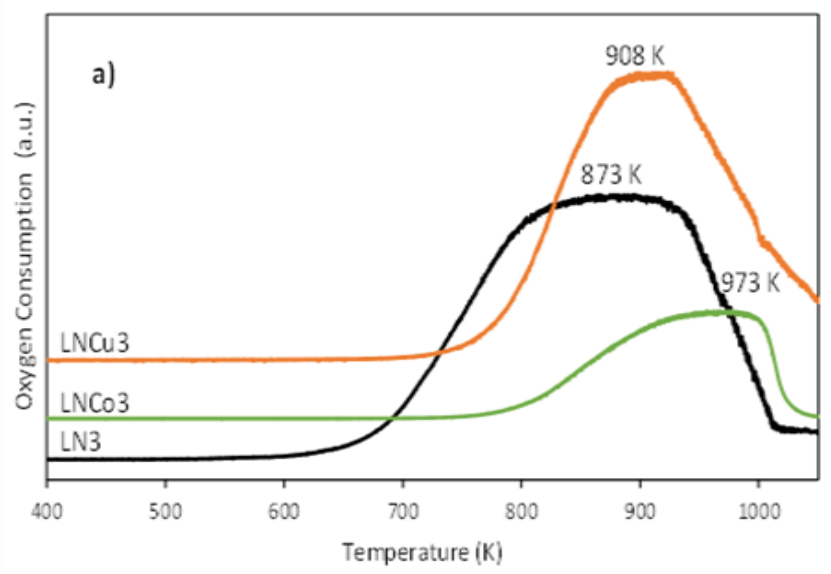

\section{Conclusion}

The reactivity of $\mathrm{LaNi}_{0.9} \mathrm{M}_{0.1} \mathrm{O}_{3}$ (LNM3) and $\mathrm{La}_{2} \mathrm{Ni}_{0.9} \mathrm{M}_{0.1} \mathrm{O}_{4}$ (LNM4) catalysts with $\mathrm{M}=\mathrm{Co}$, $\mathrm{Cu}$, prepared by partial substitution of $\mathrm{Ni}$ by $\mathrm{Co}$ or $\mathrm{Cu}$ using sol-gel method, was studied in the dry reforming of methane (DRM) for syngas $\left(\mathrm{CO}+\mathrm{H}_{2}\right)$ production and their performances were compared to those of $\mathrm{LaNiO}_{3}$ perovskite and $\mathrm{La}_{2} \mathrm{NiO}_{4}$ spinel. The obtained results highlighted the effect of: (i) the structure type, and (ii) the substitution of nickel by cobalt or copper on the catalytic activity and stability. The reducibility and activity results revealed better catalytic performances in the case of perovskite structure (LN3) due to its high reducibility compared to the spinel one (LN4). The nickel substitution in the $\mathrm{LaNiO}_{3}$ perovskite and $\mathrm{La}_{2} \mathrm{NiO}_{4}$ spinel structures by cobalt or copper strongly influences the activation temperature of methane and the stability of the catalytic performances over reaction time. The presence of cobalt improves the catalytic stability leading to higher and more stable conversions of $\mathrm{CH}_{4}$ and $\mathrm{CO}_{2}$ and syngas $\left(\mathrm{H}_{2}+\right.$ $\mathrm{CO})$ production with a low carbon deposition compared to copper samples. These results are strongly related to a synergistic effect between $\mathrm{Ni}$ and Co that enhances the catalytic performances in the DRM reaction.

\section{Acknowledgements}

The authors would like to thank: Ministère de l'Enseignement Supérieur et de la Recherche Scientifique (MESRS), Alger Algérie for the PNE graduate scholarship that allowed the funding and the achievement of this work.

Figure 10. TPO profiles of spent catalysts (after $65 \mathrm{~h}$ of catalytic test at $1073 \mathrm{~K}$ ): a) LNM3 and b) LNM4 $(\mathrm{M}=\mathrm{Co}, \mathrm{Cu})$.

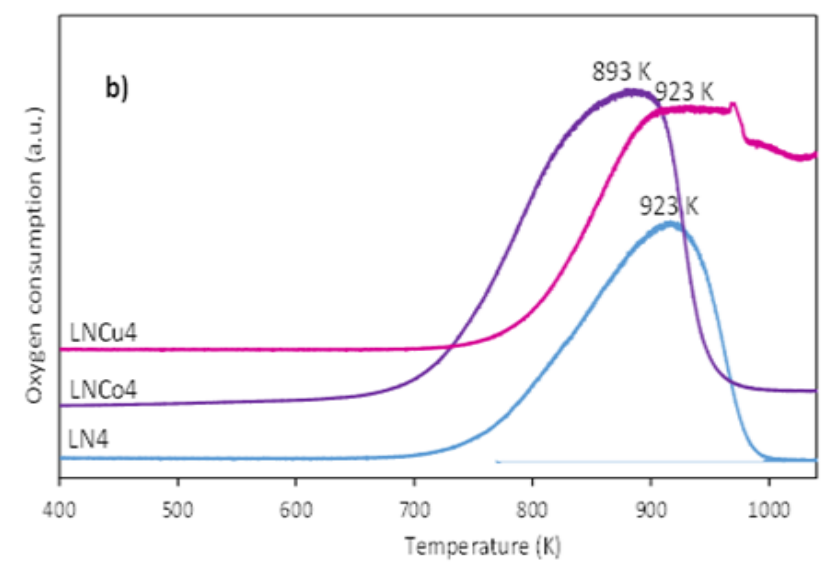




\section{References}

[1] Wood, D.A., Nwaoha, C., Towler, B.F. (2012). Gas-to-liquids (GTL): a review of an industry offering several routes for monetizing natural gas. J. Nat. Gas. Sci. Eng., 9, 196-208. doi: 10.1016/j.jngse.2012.07.001

[2] Iglesias, I., Forti, M., Baronetti, G., Marino, F. (2019). Zr-enhanced stability of ceria based supports for methane steam reforming at severe reaction conditions. Int. J. Hydrogen Energ., 44, 8121-8132. doi: 10.1016/j.ijhydene.2019.02.070

[3] Messaoudi, H., Thomas, S., Djaidja, A., Slyemi, S., Barama, A. (2018). Study of $\mathrm{La}_{x} \mathrm{NiO}_{y}$ and $\mathrm{La}_{x} \mathrm{NiO}_{y} / \mathrm{MgAl}_{2} \mathrm{O}_{4}$ catalysts in dry reforming of methane. J. $\mathrm{CO}_{2}$ Util., 24, 40-49. doi: 10.1016/j.jcou.2017.12.002

[4] Messaoudi, H., Thomas, S., Djaidja, A., Slyemi, S., Chebout, R., Barama, S., Barama, A., Benaliouche, F. (2017). Hydrogen production over partial oxidation of methane using Ni-Mg-Al spinel catalysts: a kinetic approach. C.R. Chim., 20, 738-746. doi: 10.1016/j.crci.2017.02.002

[5] Zhang, G., Liu, J., Xu, Y., Sun, Y. (2018). A review of $\mathrm{CH}_{4}-\mathrm{CO}_{2}$ reforming to synthesis gas over Ni-based catalysts in recent years (20102017). Int. J. Hydrogen Energ., 43, $\begin{array}{llllllllllll}1 & 5 & 0 & 3 & 0 & - & 1 & 5 & 0 & 5 & 4\end{array} . \quad \mathrm{d}$ o $\mathrm{i}$ : 10.1016/j.ijhydene.2018.06.091

[6] Kusakabe, K., Sotowa, K.-I., Eda, T., Iwamoto, Y. (2004). Methane steam reforming over $\mathrm{Ce}-\mathrm{ZrO}_{2}$ supported noble metal catalysts at low temperature. Fuel Proc. Tech., 86, 319-326. doi: 10.1016/j.fuproc.2004.05.003

[7] Profeti, L.P.R., Ticianelli, E.A., Assaf, E.M. (2008). $\mathrm{Co} / \mathrm{Al}_{2} \mathrm{O}_{3}$ catalysts promoted with noble metals for production of hydrogen by methane steam reforming. Fuel, 87, 2076-2081. doi: 10.1016/j.fuel.2007.10.015

[8] Swaan, H.M., Kroll, V.C.H., Martin, G.A., Mirodatos, C. (1994). Deactivation of supported nickel catalysts during the reforming of methane by carbon dioxide. Catal. Today, 21, 571-578. doi: 10.1016/0920-5861(94)80181-9

[9] Özdemir, H., Öksüzömer, M.A.F., Gürkaynak, M.A. (2010). Preparation and characterization of $\mathrm{Ni}$ based catalysts for the catalytic partial oxidation of methane: Effect of support basicity on $\mathrm{H}_{2} / \mathrm{CO}$ ratio and carbon deposition. Int. J. Hydrogen Energ., 35, 12147-12160. doi: 10.1016/j.ijhydene.2010.08.091

[10] Al-Fatesh, A.S., Kumar, R., Kasim, S.O., Ibrahim, A.A., Fakeeha, A.H., Abasaeed, A.E., Alrasheed, R., Bagabas, A., Chaudhary, M.L., Frusteri, F., Chowdhury, B. (2020). The effect of modifier identity on the performance of $\mathrm{Ni}$ based catalyst supported on $\mathrm{Y}^{-} \mathrm{Al}_{2} \mathrm{O}_{3}$ in dry re- forming of methane. Catal. Today, 348, 236-242. doi: 10.1016/j.cattod.2019.09.003

[11] Wang, F., Wang, Y., Zhang, L., Zhu, J., Han, B., Fan, W., Xu, L., Yu, H., Cai, W., Li, Z., Deng, Z., Shi, W. (2020). Performance enhancement of methane dry reforming reaction for syngas production over $\mathrm{Ir} / \mathrm{Ce}_{0.9} \mathrm{La}_{0.1} \mathrm{O}_{2}$ nanorods catalysts. Catal. Today, 355, 502511. doi: 10.1016/j.cattod.2019.06.067

[12] Benrabaa, R., Barama, A., Boukhlouf, H., Guerrero-Caballero, J., Rubbens, A., BordesRichard, E., Löfberg, A., Vannier, R.N. (2017). Physico-chemical properties and syngas production via dry reforming of methane over $\mathrm{NiAl}_{2} \mathrm{O}_{4}$ catalyst. Int. J. Hydrogen Energ., 42, 12989-12996. doi: 10.1016/j.ijhydene.2017.04.030

[13] Dama, S., Ghodke, S.R., Bobade, R., Gurav, H.R., Chilukuri, S. (2018). Active and durable alkaline earth metal substituted perovskite catalysts for dry reforming of methane. Appl. Catal. B: Environ., 224, 146-158. doi: 10.1016/j.apcatb.2017.10.048

[14] Song, X., Dong, X., Yin, S., Wang, M., Li, M., Wang, H. (2016). Effects of Fe partial substitution of $\mathrm{La}_{2} \mathrm{NiO}_{4} / \mathrm{LaNiO}_{3}$ catalyst precursors prepared by wet impregnation method for the dry reforming of methane. Appl. Catal. A: Gen., $\quad 526, \quad 132-138$. d o i : 10.1016/j.apcata.2016.07.024

[15] Guo, J., Lou, H., Zhao, H., Chai, D., Zheng, X. (2004). Dry reforming of methane over nickel catalysts supported on magnesium aluminate spinels. Appl. Catal. A: Gen., 273, 75-82. doi: 10.1016/j.apcata.2004.06.014

[16] Li, Z., Li, M., Bian, Z., Kathiraser, Y., Kawi, S. (2016). Design of highly stable and selective core/yolk-shell nanocatalysts-A review. Appl. Catal. B: Environ., 188, 324-341. doi: 10.1016/j.apcatb.2016.01.067

[17] Peng, H., Zhang, X., Zhang, L., Rao, C., Lian, J., Liu, W., Ying, J., Zhang, G., Wang, Z., Zhang, N., Wang, X. (2017). One-Pot Facile Fabrication of Multiple Nickel Nanoparticles Confined in Microporous Silica Giving a Multiple-Cores@Shell Structure as a Highly Efficient Catalyst for Methane Dry Reforming. ChemCatChem., 9, 127-136. doi: 10.1002/cctc. 201601263

[18] Dai, C., Zhang, S., Zhang, A., Song, C., Shi, C., Guo, X. (2015). Hollow zeolite encapsulated Ni-Pt bimetals for sintering and coking resistant dry reforming of methane. J. Mater. Chem. A, 3, 16461-16468. doi: 10.1039/C5TA03565A

[19] Zhu, Y., Jin, N., Liu, R., Sun, X., Bai, L., Tian, H., Ma, X., Wang, X. (2020). Bimetallic $\mathrm{BaFe}_{2} \mathrm{MAl}_{9} \mathrm{O}_{19}(\mathrm{M}=\mathrm{Mn}, \mathrm{Ni}$, and $\mathrm{Co})$ hexaaluminates as oxygen carriers for chemical loop- 
ing dry reforming of methane. Appl. Energy, $258, \quad 114070-114074$. do i : 10.1016/j.apenergy.2019.114070

[20] Horlyck, J., Lawrey, C., Lovell, E.C., Amal, R., Scott, J. (2018). Elucidating the impact of $\mathrm{Ni}$ and Co loading on the selectivity of bimetallic NiCo catalysts for dry reforming of methane. Chem. Eng. J., 352, 572-580. doi: 10.1016/j.cej.2018.07.009

[21] Song, K., Lu, M., Xu, S., Chen, C., Zhan, Y., Li, D., Au, C., Jiang, L., Tomishige, K. (2018). Effect of alloy composition on catalytic performance and coke-resistance property of $\mathrm{Ni}$ $\mathrm{Cu} / \mathrm{Mg}(\mathrm{Al}) \mathrm{O}$ catalysts for dry reforming of methane. Appl. Catal. B: Environ., 239, 324-333. doi: 10.1016/j.apcatb.2018.08.023

[22] Fan, M.S., Abdullah, A.Z., Bhatia, S. (2010). Utilization of greenhouse gases through carbon dioxide reforming of methane over $\mathrm{Ni}-$ $\mathrm{Co} / \mathrm{MgO}-\mathrm{ZrO}_{2}$ : Preparation, characterization and activity studies. Appl. Catal. B: Environ., $\begin{array}{lllllll}1 & 0 & 0\end{array} \quad 365-377 . \quad \mathrm{d}$ o $\mathrm{i}$ : 10.1016/j.apcatb.2010.08.013

[23] Nataj, S.M.M., Alavi, S.M., Mazloom, G. (2018). Modeling and optimization of methane dry reforming over $\mathrm{Ni}-\mathrm{Cu} / \mathrm{Al}_{2} \mathrm{O}_{3}$ catalyst using Box-Behnken design. J. Energy Chem., 27, 1475-1488. doi: 10.1016/j.jechem.2017.10.002

[24] Shiri, A., Soleymanpour, F., Eshghi, H., Khosravi, I. (2015). Nano-sized $\mathrm{NiLa}_{2} \mathrm{O}_{4}$ spinel- $\mathrm{NaBH}_{4}$-mediated reduction of imines to secondary amines. Chin. J. Catal., 36, 1191-1196. doi: 10.1016/S18722067(15)60921-4

[25] Valderrama, G., Kiennemann, A., Goldwasser, M.R. (2008). Dry reforming of $\mathrm{CH}_{4}$ over solid solutions of $\mathrm{LaNi}_{1-\mathrm{x}} \mathrm{Co}_{\mathrm{x}} \mathrm{O}_{3}$. Catal. Today, 133-135, 142-148. doi: 10.1016/j.cattod.2007.12.069

[26] Leofanti, G., Padovan, M., Tozzola, G., Venturelli, B. (1998). Surface area and pore texture of catalysts. Catal. Today, 41, 207-219. doi: 10.1016/S0920-5861(98)00050-9

[27] Valderrama, G., Kiennemann, A., Goldwasser, M.R. (2010). La-Sr-Ni-Co-O based perovskite-type solid solutions as catalyst precursors in the $\mathrm{CO}_{2}$ reforming of methane. J. Power Sources, 195, 1765-1771. doi: 10.1016/j.jpowsour.2009.10.004

[28] Moradi, G.R., Khosravian, F., Rahmanzadeh, M. (2012). Effects of Partial Substitution of Ni by $\mathrm{Cu}$ in $\mathrm{LaNiO}_{3}$ Perovskite Catalyst for Dry Methane Reforming. Chinese J. Catal., 33, 797-801.doi: 10.1016/S1872-2067(11)60378-1

[29] Banerjee, A., Das, S., Mirsa, S., Mukhopadhyay, S. (2009). Structural analysis on spinel $\left(\mathrm{MgAl}_{2} \mathrm{O}_{4}\right)$ for application in spinel-bonded castables. Ceramics Int., 35, 381-390. doi: 10.1016/j.ceramint.2007.11.009
[30] Guo, J., Lou, H., Zhao, H., Wang, X. (2004). Novel synthesis of high surface area $\mathrm{MgAl}_{2} \mathrm{O}_{4}$ spinel as catalyst support. Mat. Let., 58, 1920-1923. doi: 10.1016/j.matlet.2003.12.013

[31] Phan, T.S., Sane, A.R., de Vasconcelos, B.R., Nzihou, A., Sharrock, P., Grouset, D., Pham Minh, D. (2018). Hydroxyapatite supported bimetallic cobalt and nickel catalysts for syngas production from dry reforming of methane. Appl. Catal. B: Environ., 224, 310-321. doi: 10.1016/j.apcatb.2017.10.063

[32] Verykios, X.E. (2003). Catalytic dry reforming of natural gas for the production of chemicals and hydrogen. Int. J. Hydrogen Energ., 28, 1045-1063. doi: 10.1016/S03603199(02)00215-X

[33] Zhang, J., Wang, H., Dalai, A.K. (2007). Development of stable bimetallic catalysts for carbon dioxide reforming of methane. $J$. Catal., $249, \quad 300-310$. doi : 10.1016/j.jcat.2007.05.004

[34] Takanabe, K., Nagaoka, K., Nariai, K., Aika, K. (2005). Titania-supported cobalt and nickel bimetallic catalysts for carbon dioxide reforming of methane. J. Catal., 232, 268-275. doi: 10.1016/j.jcat.2005.03.011

[35] González, O., Lujano, J., Pietri, E., Goldwasser, M.R. (2005). New Co-Ni catalyst systems used for methane dry reforming based on supported catalysts over an INT-MM1 mesoporous material and a perovskite-like oxide precursor $\mathrm{LaCo}_{0.4} \mathrm{Ni}_{0.6} \mathrm{O}_{3}$. Catal. Today, $107-108, \quad 436-443$. d o i : 10.1016/j.cattod.2005.07.112

[36] Song, X., Dong, X., Yin, S., Wang, M., Li, M., Wang, H. (2016). Effects of Fe partial substitution of $\mathrm{La}_{2} \mathrm{NiO}_{4} / \mathrm{LaNiO}_{3}$ catalyst precursors prepared by wet impregnation method for the dry reforming of methane. Appl. Catal. A: Gen., $\quad 526, \quad 132-138$. do i : 10.1016/j.apcata.2016.07.024

[37] Djaidja, A., Libs, S., Kiennemann, A., Barama, A. (2006). Characterization and activity in dry reforming of methane on $\mathrm{NiMg} / \mathrm{Al}$ and $\mathrm{Ni} / \mathrm{MgO}$ catalysts. Catal. Today, $113, \quad 194-200 . \quad$ d o i : 10.1016/j.cattod.2005.11.066

[38] Djaidja, A., Messaoudi, H., Kaddeche, D., Barama, A. (2015). Study of $\mathrm{Ni}-\mathrm{M} / \mathrm{MgO}$ and $\mathrm{Ni}-\mathrm{M}-\mathrm{Mg} / \mathrm{Al}(\mathrm{M}=\mathrm{Fe}$ or $\mathrm{Cu})$ catalysts in the $\mathrm{CH}_{4}-\mathrm{CO}_{2}$ and $\mathrm{CH}_{4}-\mathrm{H}_{2} \mathrm{O}$ reforming. Int. J. Hydrogen Energ., 40, 4989-4995. doi: 10.1016/j.ijhydene.2014.12.106 